\begin{tabular}{|c|c|c|c|c|c|c|}
\hline \multirow{4}{*}{ Impact Factor: } & ISRA (India) & $=3.117$ & SIS (USA) & $=0.912$ & ICV (Poland) & $=6.630$ \\
\hline & ISI (Dubai, UAE & $=0.829$ & РИНЦ (Russia & $=0.156$ & PIF (India) & $=1.940$ \\
\hline & GIF (Australia) & $=0.564$ & ESJI (KZ) & $=8.716$ & IBI (India) & $=4.260$ \\
\hline & JIF & $=1.500$ & SJIF (Morocce & $=5.667$ & OAJI (USA) & $=0.350$ \\
\hline
\end{tabular}

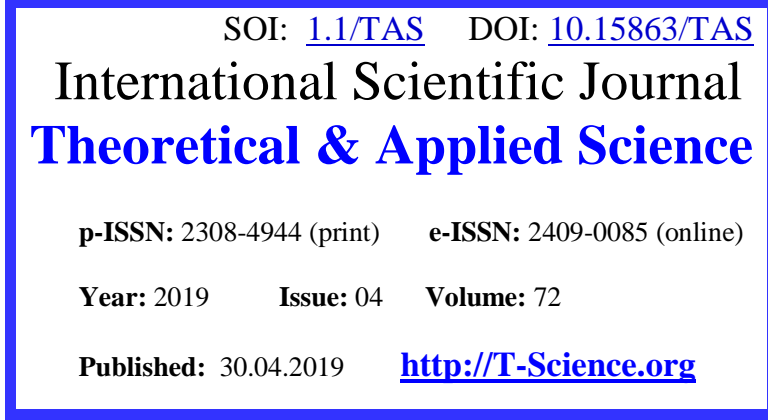

SECTION 13. Geography. History. Oceanology. Meteorology.
QR - Issue

QR - Article

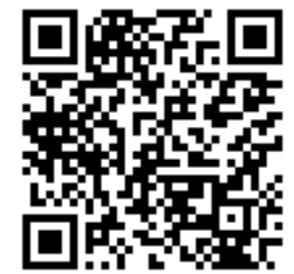

U.A. Usarov

$\mathrm{PhD}$ researcher,

National University of Uzbekistan, Tashkent, Republic of Uzbekistan umidjon.usarov@mail.ru

A.B. Sharipova Student,

National University of Uzbekistan, Tashkent, Republic of Uzbekistan

\title{
IN WRITTEN COURSES OF THE MIDDLE AGES TOPONYMS REGARDING TO THE HISTORY OF FARMING AND IRRIGATION SYSTEM OF BOTTOM ZARAFSHAN OASIS
}

Abstract: This article analyzes the culture of farming and the history of land and water relations, as well as the system of irrigation. Particular attention is paid to the study of sources of the Middle Ages related to the land and water relations in the Bukhara oasis.

Key words: Central Asia, Bukhara oasis, Mawarannahr (Transoxiana), Amu Darya, Syr Darya, Zarafshan, irrigation system, land and water relations, Samanid Empire, "History of Bukhara", "Hudud al-Alam", "Kitab Surat al-Ard" ("Book of the Description of the Earth"), "Baburnama”.

Language: English

Citation: Usarov, U. A., \& Sharipova, A. B. (2019). In written courses of the middle ages toponyms regarding to the history of farming and irrigation system of bottom Zarafshan oasis. ISJ Theoretical \& Applied Science, 04 (72), 554-556.

Soi: http://s-o-i.org/1.1/TAS-04-72-75 Doi: crostef https://dx.doi.org/10.15863/TAS.2019.04.72.75

\section{Introduction}

Culture of farming which was adapted for system of artificial irrigation came into existence in the bottom of Amu Darya, Syr Darya, Zarafshan and other rivers which were considered as great water sources in the territory of Central Asia long since. Local peoples possessed a lot of experiments and methods which was based on productive using from earth and water resources, as a result of this, sowing areas, gardens and all branches of agriculture were extended and developed in the oasises.

Long since in written sources was admitted as one of the largest centers, where socio-economical and cultural relations were developed, in Central Asia. In the East had its place as commerce and handicrafting made progress there. Especially, Bukhara city played a significant role as an administrative center in the political life of the country.

Materials and methods
History of irrigation culture of the oasis was reflected in the written courses which were created in the medieval centuries and written by Arabic historians too. These courses include "History of Bukhara" by Abu Bakr Mukhammad ibn Ja'far anNarshakhiy, "Hudud al-"Alam" (its author is unknown), "Kitab Surat al-Ard" ("the book of Description of the Earth") by Ibn Khavkal, "Baburnama" by Zakhiriddin Mukhammad Babur, "Abdullanama" by Khofiz Tanish al-Bukhari and other books[1].

According to these works, numerous differentsized urban and rural areas were located in the oasis of the bottom Zarafshan and its surroundings that in these territories agriculture, cattle-raising, handicrafting efficiently made progress. Particularly, in the oasis agriculture were improved, as a result of this, abundant harvest was gathered. The oasis of the bottom Zarafshan and its surrounding rural areas were well provided with the water. 


\begin{tabular}{|c|c|c|c|c|c|c|}
\hline \multirow{4}{*}{ Impact Factor: } & ISRA (India) & $=\mathbf{3 . 1 1 7}$ & SIS (USA) & $=0.912$ & ICV (Poland) & $=6.630$ \\
\hline & ISI (Dubai, UAE & $=0.829$ & РИНЦ (Russia & $=0.156$ & PIF (India) & $=1.940$ \\
\hline & GIF (Australia) & $=0.564$ & ESJI (KZ) & $=8.716$ & IBI (India) & $=4.260$ \\
\hline & JIF & $=1.500$ & SJIF (Morocco & $=5.667$ & OAJI (USA) & $=0.350$ \\
\hline
\end{tabular}

At the bottom of Zarafshan oasis about important historical events, that is to say, from appearance of hunting, fishing industry and farming, creation of large ancient rural areas such as, Navmichkand, Poykand, Afshona, Varakhsha, Romitan, Vardona whose names were written, till the construction of Bukhara city many significant data were stated in the book named after "History of Bukhara" by Abu Bakr Mukhammad ibn Ja'far anNarshakhiy[2, P. 81-173].

Additionally, in this book a lot of information was given about land and water relations and we can see the following definitions: "dehkan", - that is, "the mayor of the rural areas", working farmers "kashovarz"- that is, kushchi who ploughs the earth, "kadivar" -rural areas' people who were subordinate to rich land owners. In this source precious facts were stated about irrigaton system of the bottom of Zarafshan oasis, rural areas which are situated in the bank of large canals, gardens, rabats and kushks. Especially, in VIII -XII centuries names of the hydrotoponyms were written for instance, Karmana, Shapurkam, Kharkonat ul-Ulyo, Kharkonrud, Ovkhirfar, Somjan, Baykonrud, Faroviz is-Suflo or Komil Daymun, Avan, Kayfur, Rudi Zar which provided with water Zarafshan oasis[2. P. 110-111].

Mukhammad Narshakhiy noted a lot of precious information about history of coming to existence of canals and streams which deliver water in the oasis too. To illustrate, he told about history of being discovered of Shapirkam hydrotoponym that Shapirkam was one of the largest irrigation canals in the bottom of Zarafshan oasis and local people of Bukhara named as Shafirkam. According to the author, one of the successors of Kisro (Khisrav I (531578) or Khisrav II (590-628) who are belonging to Sasanid dynasty, quarreled with his father and he came to Bukhara region. His name was "Shapur". A word of "Pur" means "son" in Iran language. When he came to Bukhara, Bukharkhudot who governed the bottom of Zarafshan oasis accepted very well. Shapur loved hunting. One day he started to hunt and suddenly reached in the direction of Shapirkam. At then, there were no rural area and comfortable destination, only summer pasture and the spot where people hunted were available. Shapur liked this territory and asked for Bukharkhudat with favour that he should give this area to Shapur as a share because Shapur aimed to develop it. After he accepted this land, he ordered to dig a large irrigation canal. Shapur gave his name for it and was started to be named as "Shapirkam". Afterwards, on the bank of this irrigation canal villages and castles were built $[2, \mathrm{P}$. 110].

Bukhara was the largest and comfortable city, very rich in luxuries and the capital of Samanid Empire which ruled the East. It was said in the historical geographical book of "Hudud al-'Alam"(its author is unknown): "Its climate is wet, fruit and running water is very much" [3, P. 66]. In addition, in this source it was written that people of the oasis were expert shot and able to score a victory; high-quality woolen carpet, thick woolen fabric, prayer-mat were prepared; pashmin and sho'ra were produced as well as merchandised to other places. Moreover, territory of the bottom Zarafshan oasis is horizontal twelve farsang and vertical twelve farsang, its sircumference was surrounded with uninterrupted wall together with its all rabats and rural areas were situated inside the wall[4, P. 11-12].

We can see in the book of "Hudud al-"Alam" the following facts: "Four rivers starts to flow mountainous areas of Middle Butamon (Zarafshan mountain) of Bukhara river (Zarafshan river), after six farsang flows, four of them turns round batixi (lake) by joining and it is called "Small river". Sarushana is the beginning of the river, it runs in Samarkand and Sugd areas as well as the center of bottom of Zarafshan oasis and one part of water is spent at sowing areas of Bukhara"[4, P. 12]. Additioanally, in the source it was told that several tributaries of Zarafshan river are poured in Amu Darya. Generally, it was emphasized in the source that guarantee of water was well organized in the oasis. This played a main role for development of farming, gardening, fielding.

Information related to irrigation system of Bukhara oasis was given in the book of "Kitab Surat al-Ard" ("the book of Description of the Earth") by arabic geographer and historian scientist Ibn Khavkal. In the source it was lighted about irrigation ditches which stretches out Bukhara city and Bukhara oasis, their geographic location, areas which was provided with water[5, P 40-51]. Particularly, it was stated that Bukhara city took running water the largest Bukhara river (it is considered zarafshan river) which started to flow from Samarkand, from this river several irrigation ditches were digged to the city, one of them is named "Fashirdiza" (Fashirdiza or Fashidiza according to the sources, it is a name of the village close to Bukhara. There is sogdian word - "diza" in the structure of the name of irrigation ditch and village. Generally, the fortress was situated in this village.), it flew by the area of "Darb Murdkashon" and "Juybar Ibrakhim" gates and reached "Bob alBal'amin" gate and from that location it was poured the irrigation ditch whose is "Navkanda" (Navkanda remain water of all irrigation ditches of Bukhara city flew into this ditch. Navkanda means "new irrigation ditch" in sugdian language). This irrigation ditch provided approximately two thousand gardens which was located in its surrounding, castles and other areas with water [5, P. 42]. It is clear that irrigation system of the oasis was well organized.

It was written in the source that numerous irrigation ditches such as, Juybar Bokor, Juybar alKavoririyn, Ju-yi Gashadj, Nahr Baikand, Navkada, at-Tahuna, nahr Kushna, Raboh, ar-Registon, Nahr 


\begin{tabular}{|c|c|c|c|c|c|c|}
\hline \multirow{4}{*}{ Impact Factor: } & ISRA (India) & $=3.117$ & SIS (USA) & $=0.912$ & ICV (Poland) & $=6.630$ \\
\hline & ISI (Dubai, UAE & $=0.829$ & РИНЦ (Russia) & $=0.156$ & PIF (India) & $=1.940$ \\
\hline & GIF (Australia) & $=0.564$ & ESJI (KZ) & $=8.716$ & IBI (India) & $=4.260$ \\
\hline & JIF & $=1.500$ & SJIF (Morocco & $=5.667$ & OAJI (USA) & $=0.350$ \\
\hline
\end{tabular}

Zugorkanda[5, P. 42-44] provided castles, gardens and many areas of Bukhara city with water.

Ibn Khavkal told that Nahr as-Sugd (it is a sugdian name of Zarafshan river) which descends from mountainous areas of al-Buttam (Al-Buttam Arabic name of mountainous area which is situated in the bottom trend of Zarafshan river. It written as Buttamon in Persian sources. Beginning of Bukhara river was named as Central Butamon (Buttamon) in the book of Hudud ul-olam. According to this book, it was started from Zarafshan mountainous area) and flows to the bottom of Zarafshan oasis by Samarkand provided the bottom of Zarafshan oasis with water. A lot of irrigation ditches which were digged from $\mathrm{Nahr}$ as-Sugd watered rural areas and plantions which is situated in the wall of Bukhara. For example, Bukhara and its surroundings were watered by several large irrigation ditches like Shafirkom, Khargon- rud, najor Xiftar, Nahr Jarg, Navkanda, nahr Barasha, Nahr Kushna, Nahr ar-Romiton, Bottom farovuz, Arvon, Top Farovuz, Khoma Nahr Navkada. As water was very much in the irrigation ditches, boats swam too[5, P. 45-46]. Farming of villages of the bottom of Zarafshan oasis was supplied with water by these irrigation ditches.

Facts about irrigation sytem of the bottom of Zarafshan oasis, problems of farming was stated in the book of "Baburnama" by Zakhiriddin Mukhammad Babur[6, P. 61]. In this source it was noted that Bukhara oasis was one of the largest centres of Mawarannahr in XV century. Different kind of fruits and vegetables were planted in Bukhara and its regions. Generally, Zakhiriddin Mukhammad Babur said: "There are not very many and delicious melons like melons of Bukhara in Mawarannahr... you can see various melons and they are quite tasty" [7, P. 112]. It is clear from these facts that farming was developed extremely well in the bottom of Zarafshan oasis in the Middle ages.

\section{Conclusion}

To recapitulate, we can learn about comfortable natural-geographic condition of the bottom of Zarafshan oasis, sources of rich water by researching toponyms related to history of farming and irrigation of the oasis. From ancient periods a basic occupation of population of Central Asia, especially population of Zarafshan oasis was farming which was related to artificial watering system. Most of the people of Zarafshan oasis inhabited in the rural areas, they did the main branches of agriculture, that is, farming, gardening, fielding. In addition, experienced peoples of Central Asia had typical methods of watering, these methods helped to use cleverly water sources of fertile soils, rivers and irrigation ditches. We can see it by models of development of irrigation technics which is not available in other areas. By being based on names of places which was aforementioned in the sources, it is concluded that farming and irrigation system was well organized in the territory of the bottom of Zarafshan oasis which was one of the largest socioeconomical centers of Central Asia.

\section{References:}

1. Abu Bakr Mukhammad ibn Ja'far an-Narshakhiy (1991). History of Bukhara. Translation from Persia by A.Rasulev. Tashkent: Kamalak.

2. (2007). Hudud ul-olam. Tashkent.: Uzbekistan, 2007. (O.Buriev. Translation from Persia, the author of introduction, definitions and indication of toponyms).

3. (2011). Ibn Havkal. Kitab surat al-Ard.Tashkent: National encyclopedia of Uzbekistan. (SH.K.Kamoliddinov is the author of definitions and translation from Arabic language).

4. Hofiz Tanish al-Bukhariy (2000). Abdullanama ("Sharafnomayi shohiy"). Chapter I and II. Translation from Persia by S.Mirzaev va Y.Hakimjonov. Tashkent: Sharq.

5. Zakhiriddin Muhammad Babur (1990). Baburnama. Tashkent.: Yulduzcha.

6. Abu Bakr Mukhammad ibn Ja'far an-Narshaxiy (1991). History of Bukhara. (pp.81-173). Tashkent, Kamalak.
7. Usarov, U. A. (2015). Izuchenie toponimov Sredney Azii, kak vazhneyshikh istoricheskikh istochnikov. VII mezhdunarodnaya nauchnoprakticheskaya konferentsiya: Otechestvennaya nauka $\mathrm{v}$ epokhu izmeneniy: postulaty proshlogo i teorii novogo vremeni. № 2, chast' 9. (p.66). Ekaterinburg.

8. (2008). Hudud ul-olam. Translation from Persia by O.Buriev. (p.11-12). Tashkent, Uzbekistan.

9. (2011). Ibn Havkal. Kitob surat al-ard. (pp.4051). Tashkent: National encyclopedia of Uzbekistan.

10. Zakhiriddin, M. B. (1990). Baburnama. (p.61). Tashkent.: Yulduzcha.

11. Buriev, O. (2015). Pages of historical geography of Central Asia (research of written sources and translations). (p.112). Tashkent: Tafakkur. 